Article

\title{
Underestimates of Grassland Gross Primary Production in MODIS Standard Products
}

\author{
Xiaoyan Zhu ${ }^{1,2}$, Yanyan Pei ${ }^{1}$, Zhaopei Zheng ${ }^{2, *}$, Jinwei Dong ${ }^{1,3, *}$, , Yao Zhang ${ }^{4}(\mathbb{D}$, \\ Junbang Wang ${ }^{1}$, Lajiao Chen ${ }^{5}$, Russell B. Doughty ${ }^{4} \mathbb{D}$, Geli Zhang ${ }^{4}$ and Xiangming Xiao ${ }^{4,6} \mathbb{D}^{\mathbb{D}}$ \\ 1 Key Laboratory of Land Surface Pattern and Simulation, Institute of Geographic Sciences and Natural \\ Resources Research, Chinese Academy of Sciences, Beijing 100101, China; zhuxy020821@126.com (X.Z.); \\ peiyy@igsnrr.ac.cn (Y.P.); jbwang@igsnrr.ac.cn (J.W.) \\ 2 College of Geography and Environment, Shandong Normal University, Jinan 250358, China \\ 3 University of Chinese Academy of Sciences, Beijing 100049, China \\ 4 Department of Microbiology and Plant Biology, and Center for Spatial Analysis, University of Oklahoma, \\ Norman, OK 73019, USA; yaozhang@ou.edu (Y.Z.); russell.doughty@ou.edu (R.B.D.); \\ geli.zhang@ou.edu (G.Z.); xiangming.xiao@ou.edu (X.X.) \\ 5 Institute of Remote Sensing and Digital Earth, Chinese Academy of Sciences, Beijing 100094, China; \\ chenlj@radi.ac.cn \\ 6 Ministry of Education Key Laboratory of Biodiversity Science and Ecological Engineering, \\ Institute of Biodiversity Science, Fudan University, Shanghai, 200438, China \\ * $\quad$ Correspondence: zzp999@163.com (Z.Z.); dongjw@igsnrr.ac.cn (J.D.); Tel.: +86-10-6488-8827 (J.D.)
}

Received: 26 September 2018; Accepted: 5 November 2018; Published: 8 November 2018

check for updates

\begin{abstract}
As the biggest carbon flux of terrestrial ecosystems from photosynthesis, gross primary productivity (GPP) is an important indicator in understanding the carbon cycle and biogeochemical process of terrestrial ecosystems. Despite advances in remote sensing-based GPP modeling, spatial and temporal variations of GPP are still uncertain especially under extreme climate conditions such as droughts. As the only official products of global spatially explicit GPP, MOD17A2H (GPP has been widely used to assess the variations of carbon uptake of terrestrial ecosystems. However, systematic assessment of its performance has rarely been conducted especially for the grassland ecosystems where inter-annual variability is high. Based on a collection of GPP datasets (GPP EC) from a global network of eddy covariance towers (FluxNet), we compared GPP $\mathrm{MOD}$ and GPP $\mathrm{EC}$ at all FluxNet grassland sites with more than five years of observations. We evaluated the performance

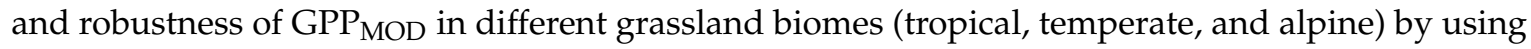
a bootstrapping method for calculating 95\% confident intervals (CI) for the linear regression slope, coefficients of determination $\left(R^{2}\right)$, and root mean square errors (RMSE). We found that GPP generally underestimated GPP by about $34 \%$ across all biomes despite a significant relationship $\left(R^{2}=0.66(\mathrm{CI}, 0.63-0.69), R M S E=2.46(2.33-2.58) \mathrm{g} \mathrm{Cm}^{-2}\right.$ day $\left.^{-1}\right)$ for the three grassland biomes. $\mathrm{GPP}_{\mathrm{MOD}}$ had varied performances with $R^{2}$ values of 0.72 (0.68-0.75) (temperate), 0.64 (0.59-0.68) (alpine), and $0.40(0.27-0.52)$ (tropical). Thus, GPP MOD performed better in low GPP situations (e.g., temperate grassland type), which further indicated that GPP $_{M O D}$ underestimated GPP. The underestimation of GPP could be partly attributed to the biased maximum light use efficiency $\left(\varepsilon_{\max }\right)$ values of different grassland biomes. The uncertainty of the fraction of absorbed photosynthetically active radiation (FPAR) and the water scalar based on the vapor pressure deficit (VPD) could have other reasons for the underestimation. Therefore, more accurate estimates of GPP for different grassland biomes should consider improvements in $\varepsilon_{\max }$, FPAR, and the VPD scalar. Our results suggest that the community should be cautious when using MODIS GPP products to examine spatial and temporal variations of carbon fluxes.
\end{abstract}

Keywords: GPP; MOD17; grassland ecosystem; grassland types; FluxNet 


\section{Introduction}

Gross primary productivity (GPP), which is also known as the rate of photosynthesis, is the biggest carbon flux of terrestrial ecosystems [1]. This carbon flux plays an important role in the terrestrial carbon cycle. GPP is also the basis for ecosystem services such as food, fuel, and wood products [2]. The ability to accurately track the spatial and temporal variability of GPP is fundamental for understanding the biogeochemical dynamics of terrestrial ecosystems [3,4]. Therefore, it is critical for us to accurately estimate GPP and further understand the trends and variations of global and regional carbon uptake. However, there still exist considerable uncertainties in GPP estimation, which has attracted plenty of attention [5-7].

Satellite remote sensing provides an unprecedented and practical opportunity to estimate ecosystem GPP at large scales by using a diagnostic approach. Numerous remote sensing models have been proposed including the Global Production Efficiency Model (GLOPEM) [8], the Carnegie-Ames-Stanford Approach model (CASA) [9], the Vegetation Photosynthesis Model (VPM) [10,11], the light use efficiency model (EC-LUE) [12], and the net photosynthesis model (PSN) [13]. The Moderate Resolution Imaging Spectroradiometer (MODIS) primary production products (MOD17A2) based on the PSN model are open access datasets with high temporal and spatial resolutions that allow for the monitoring of global GPP at the 1-km resolution every eight days [14]. Previous studies using different light use efficiency (LUE) models estimated global GPP ranging from 105 to $177 \mathrm{P} \mathrm{g} \mathrm{C} \mathrm{a}^{-1}[15,16]$ with a considerable uncertainty. Yuan et al. [17] compared seven LUE models and they found that only two models (EC-LUE and CFlux) showed higher correlations between GPP derived from eddy covariance $\left(\mathrm{GPP}_{\mathrm{EC}}\right)$ and modeled GPP and performed better in simulating inter-annual variability of GPP than others. Furthermore, the performances of different models are not the same among all vegetation types or biomes $[18,19]$. As the only official global GPP products (MOD17A2/MOD17A2H), the MODIS GPP (GPP ${ }_{M O D}$ ) products have been widely used in addressing scientific questions on terrestrial carbon uptake and carbon cycle [20,21]. For example, MOD17A2 has been used to understand the drought impact on global carbon uptake of terrestrial ecosystems [22].

However, there is still a great discrepancy about the reliability of GPP ${ }_{M O D}$ when compared with in-situ data collected in different locations [23]. Due to the unavailability of directly measured GPP data, the validation of MODIS GPP products is still challenging. The eddy covariance technique is an effective approach to evaluate GPP on the landscape scale. A previous study found that the GPP was reliable and matched well with $\mathrm{GPP}_{\mathrm{EC}}$ in the forest biome at Vancouver Island, Canada [24]. However, there are many studies that have highlighted the uncertainties of GPP

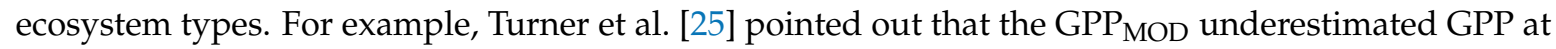
hardwood forest sites and, yet, agreed well with $\mathrm{GPP}_{\mathrm{EC}}$ data at boreal forest sites. In terms of savanna ecosystems, Leuning et al. [26] found that the GPP $\mathrm{MOD}$ performed differently for tropical wet/dry savannas. It overestimated GPP during the dry season and arid summer but matched very well during the two wet seasons. Consistent with that in Leuning et al. [26], GPP MOD underestimated GPP at dry sites located in the Sahel region, according to a study at 12 African sites of savanna ecosystems [27] while the product agreed well with $\mathrm{GPP}_{\mathrm{EC}}$ at wet sites. It showed that generally GPP $\mathrm{MOD}$ tend to be underestimated in drier forest ecosystems or savanna ecosystems. However, these studies were mostly based on the previous versions of the MODIS GPP product (Collection 4 or Collection 5), but the latest version (Collection 6) significantly improved the value of the maximum light use efficiency (for example, from $0.68 \mathrm{~g} \mathrm{C} \mathrm{m}^{-2} \mathrm{~d}^{-1} \mathrm{MJ}^{-1}$ to $0.86 \mathrm{~g} \mathrm{C} \mathrm{m}^{-2} \mathrm{~d}^{-1} \mathrm{MJ}^{-1}$ for grass) and the product footprint sizes (from $1 \mathrm{~km}$ to $500 \mathrm{~m}$ ) [28]. Whether performance has improved for collection 6 or not in these ecosystems has not been studied on a global scale.

Compared to the forest and savanna biomes, validation of the MODIS GPP in grassland has also been studied extensively. Zhang et al. [29] found that MODIS data underestimated the mean annual GPP by 30\% to 50\% in the alpine meadow sites in China. Zhu et al. [30] also found that grassland GPP (MOD17A2) was underestimated at the Haibei grassland site during the summer. In the US, Doughty et al. [31] also found that GPP $\mathrm{MOD}_{\mathrm{M}}$ performed poorly at the improved pasture sites, the native 
pasture sites, and the winter wheat sites when compared with $\mathrm{GPP}_{\mathrm{EC}}$. However, these analyses were based primarily on limited spatial and temporal coverage of in situ observations. Regional-scale and global-scale evaluations of GPP $\mathrm{MOD}_{\mathrm{D}}$ for grassland ecosystems has not yet been conducted. With the increasing global distribution of eddy flux towers and the formation of networks (e.g., FLUXNET [32], AmeriFLux [33], EuropeanFLux [34], AsiaFLux [12]), a large scale validation of GPP products has become feasible [24,35]. Recently, the latest global flux dataset of FLUXNET2015 [36] was released and it provided a great opportunity for the validation of $\mathrm{GPP} M \mathrm{MOD}$ for grassland ecosystems.

In this study, we aimed to conduct a systematic validation of $\mathrm{GPP}_{\mathrm{MOD}}$ for grassland ecosystems by using the FLUXNET2015 dataset. The overarching goals of this study are to: (1) examine the performance of $\mathrm{GPP}_{\mathrm{MOD}}$ across a network of grassland flux sites, (2) assess the uncertainties of $\mathrm{GPP}_{\mathrm{MOD}}$ under different grassland biomes (temperate, tropical, and alpine), and (3) discuss the potential reasons that cause the underestimation of GPP in the MOD17A2H products.

\section{Materials and Methods}

\subsection{GPP ${ }_{M O D}$ Algorithm}

The MOD17A2H GPP product (Collection 6) is a standard global product with a 500-m spatial resolution and eight-day temporal resolution [22]. It is based on the light use efficiency approach, which calculates GPP by using the amount of photosynthetically active radiation (PAR) absorbed by vegetation over a growing season [37]. The algorithm was developed below.

$$
G P P_{M O D}=\varepsilon \times F P A R \times P A R
$$

where $\varepsilon$ is the actual light use efficiency, $P A R$ is the photosynthetically active radiation $\left(\mathrm{MJ} \mathrm{m}^{-2}\right)$ per unit time, and FPAR is the fraction of PAR absorbed by vegetation canopy.

$$
\varepsilon=\varepsilon_{\max } \times T M I N_{\text {scalar }} \times V P D_{\text {scalar }}
$$

where $\varepsilon_{\max }\left(\mathrm{g} \mathrm{C} \mathrm{m}^{-2} \mathrm{~d}^{-1} \mathrm{MJ}^{-1}\right)$ is the maximum light use efficiency, which is given in a Biome Parameter Look-up Table (BPLUT) for each land cover type in the PSN model. The TMIN scalar $_{\text {and }}$ $V P D_{\text {scalar }}$ are environmental stress factors of temperature (daily minimum temperature, $\mathrm{Tmin},{ }^{\circ} \mathrm{C}$ ) and water (maximum daily vapor pressure deficit, VPD, Pa) and are parameterized according to Equations (3) and (4).

$$
\begin{gathered}
T M I N_{\text {scalar }}= \begin{cases}1 & T M I N>T M I N_{\text {max }} \\
\left(T M I N-T M I N_{\text {min }}\right) /\left(T M I N_{\text {max }}-T M I N_{\text {min }}\right) & T M I N_{\text {min }} \leq T M I N \leq T M I N_{\text {max }} \\
0 & T M I N<T M I N_{\text {min }}\end{cases} \\
V P D_{\text {scalar }}= \begin{cases}0 & V P D>V P D_{\text {max }} \\
\left(V P D_{\max }-V P D\right) /\left(V P D_{\max }-V P D_{\text {min }}\right) & V P D_{\min } \leq V P D \leq V P D_{\max } \\
1 & V P D<V P D_{\text {min }}\end{cases}
\end{gathered}
$$

where TMIN and $V P D$ are the daily minimum temperature $\left({ }^{\circ} \mathrm{C}\right)$ and the average vapor pressure deficit (Pa), $T M I N_{\max }$ and $V P D_{\max }$ are the daily minimum temperature and the average vapor pressure deficit at which $\varepsilon=\varepsilon_{\max }$, and $T M I N_{\min }$ and $V P D_{\min }$ are the daily minimum temperature and average vapor pressure deficit at which $\varepsilon=0[28,38]$. These parameters were determined, according to the BPLUT. The NASA Global Modeling and Assimilation Office (GMAO) provided input data for the GPP algorithm including global meteorological simulations of incoming $P A R$, daily maximum/minimum temperature, and daily maximum/minimum VPD. We downloaded MODIS Collection 6 data for 2000 to 2014 and we extracted GPP $\mathrm{MOD}$ from pixels with the 500-m resolution in which the flux towers were located. GPP $\mathrm{MOD}$ for each site was transformed from monthly totals to monthly means and were converted from $\mathrm{kg} \mathrm{C} \mathrm{m}^{-2}$ to $\mathrm{g} \mathrm{C} \mathrm{m}^{-2}$. 


\section{2. $\mathrm{CO}_{2}$ Eddy Flux and Meteorological Data}

We used the FLUXNET2015 datasets (http:/ / www.fluxdata.org) to evaluate the performance of GPP fluxes, shortwave and longwave radiations, photosynthetically active radiation, temperature, and precipitation for each flux tower site. We selected all grassland flux tower sites across the world with more than five years of observations between 2000 and 2014 using the 500-m resolution. The selection included 15 grassland sites with eddy covariance towers. All of these were included in this study (Figure 1 and Table 1). The meteorological data including precipitation, air temperature, solar radiation, and $V P D$ were used in this study. We used the gap-filled GPP data derived from the Marginal Distribution Sampling (MDS) method for gap-filling and the night-time partitioning method for the net ecosystem exchange (NEE) partitioning [39]. The daily $\mathrm{GPP}_{\mathrm{EC}}$ values were transformed to monthly $\mathrm{GPP}_{\mathrm{EC}}$ values $\left(\mathrm{g} \mathrm{C} \mathrm{m}^{-2}\right.$ day $\left.^{-1}\right)$ for a comparison with the GPP $\mathrm{MOD}$.
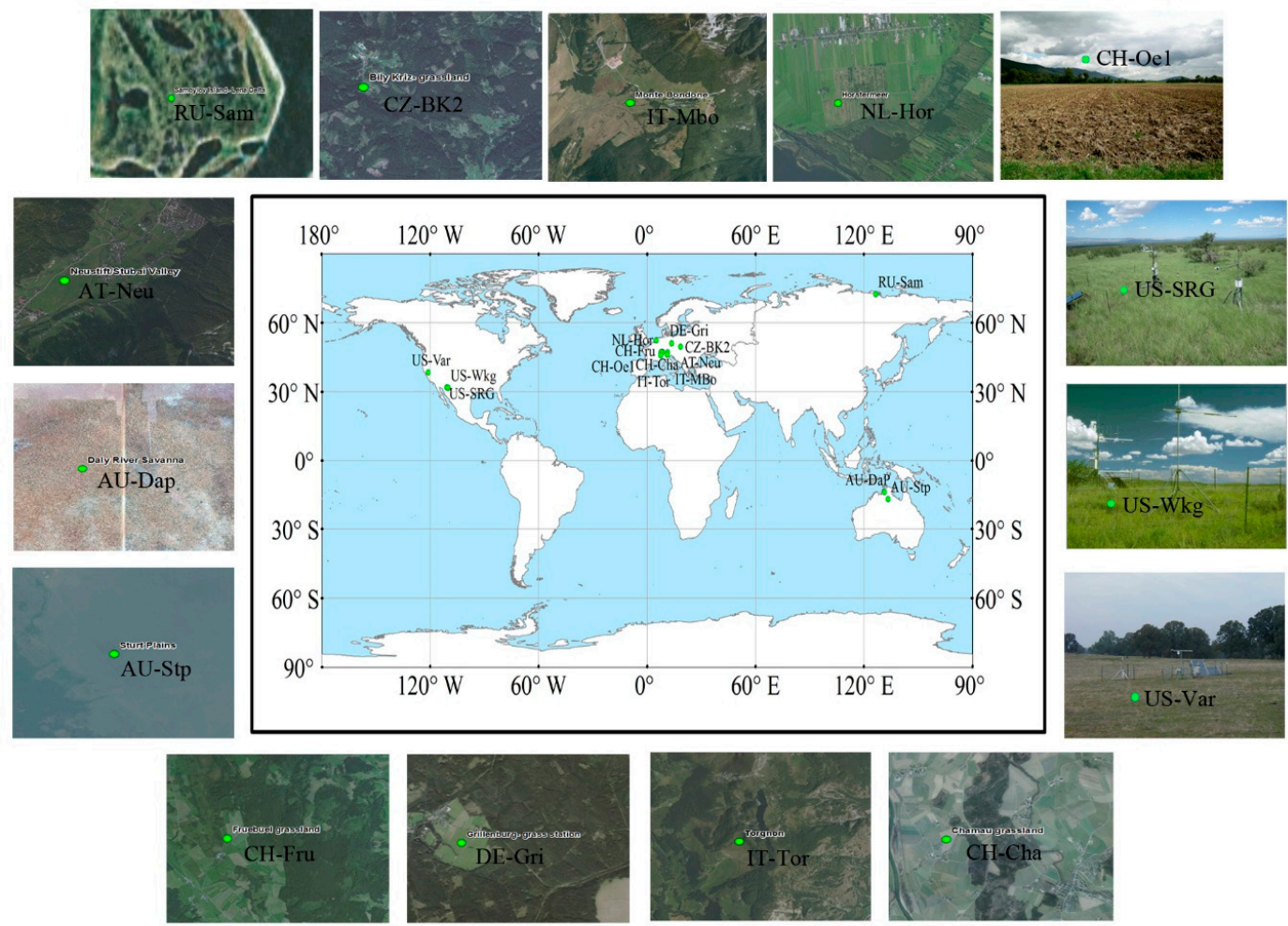

Figure 1. Distribution of 15 FLUXNET sites selected with more than five years of observations.

Table 1. Basic information of FLUXNET eddy covariance tower sites selected in this study.

\begin{tabular}{|c|c|c|c|c|c|}
\hline Site ID & Site Name & LAT & LON & IGBP Class & Data Range \\
\hline $\mathrm{CH}-\mathrm{Cha}$ & Chamau & 47.2102 & 8.4104 & Temperate grassland & 2005-2014 \\
\hline $\mathrm{CH}-\mathrm{Fru}$ & Fruebuel grassland & 47.1158 & 8.5378 & Temperate grassland & $2005-2014$ \\
\hline CH-Oe1 & Oensingen grassland & 47.2858 & 7.7319 & Temperate grassland & 2002-2008 \\
\hline DE-Gri & Grillenburg & 50.9495 & 13.5125 & Temperate grassland & 2004-2014 \\
\hline NL-Hor & Horstermeer & 52.2404 & 5.0713 & Temperate grassland & 2004-2011 \\
\hline US-SRG & Santa Rita Grasslan & 31.7894 & -110.8277 & Temperate grassland & $2008-2014$ \\
\hline US-Wkg & Walnut Gulch Kendall grasslands & 31.7365 & -109.9419 & Temperate grassland & $2004-2014$ \\
\hline AU-Dap & Daly River avanna & -14.0633 & 131.3181 & Tropical grassland & 2007-2013 \\
\hline AU-Stp & Sturt Plains & -17.1507 & 133.3502 & Tropical grassland & 2008-2014 \\
\hline US-Var & Vaira Ranch-Ione & 38.4133 & -120.9507 & Tropical grassland & 2001-2014 \\
\hline AT-Neu & Neustift & 47.1167 & 11.3175 & Alpine grassland & $2002-2012$ \\
\hline CZ-Bk2 & Bily Kriz grassland & 49.4944 & 18.5429 & Alpine grassland & 2006-2012 \\
\hline IT-Mbo & Monte Bondone & 46.0147 & 11.0458 & Alpine grassland & $2003-2013$ \\
\hline RU-Sam & Samoylov & 72.3733 & 126.4978 & Alpine grassland & 2002-2014 \\
\hline IT-Tor & Torgnon & 45.8444 & 7.5781 & Alpine grassland & 2008-2014 \\
\hline
\end{tabular}




\subsection{Evaluation of Model Performance}

In this study, GPP ${ }_{\mathrm{MOD}}$ was evaluated against GPP $\mathrm{EC}$. First, according to the climate characteristics of the grassland sites, we merged the 15 grassland sites into three grassland biomes, i.e., temperate, tropical, and alpine grasslands. Second, we evaluated the model performance by comparing the seasonal dynamics of $\mathrm{GPP}_{\mathrm{MOD}}$ and $\mathrm{GPP}_{\mathrm{EC}}$ by using the linear regression model $\left(\mathrm{GPP}_{\mathrm{EC}}=a \times \mathrm{GPP}_{\mathrm{MOD}}+b\right)$. During the evaluation, modeled data $\left(\mathrm{GPP}_{\mathrm{MOD}}\right)$ are plotted on the $\mathrm{x}$-axis and observation data $\left(\mathrm{GPP} \mathrm{EC}_{\mathrm{EC}}\right.$ on the $y$-axis. This avoids estimating spurious biases in the representation [40]. The coefficient of determination $\left(R^{2}\right)$ was used to evaluate the models' explanatory abilities for variances in GPP. Third, the root mean squared errors (RMSE) were calculated to quantify the agreement between GPP $\mathrm{EC}_{\mathrm{B} d}$ $\mathrm{GPP}_{\mathrm{MOD}}$ during the plant-growing season $\left(\mathrm{GPP}>1 \mathrm{~g} \mathrm{C} \mathrm{m}^{-2} \mathrm{day}^{-1}\right)$.

$$
R M S E=\sqrt{\frac{1}{n} \times \sum_{n=1}^{n}\left(X_{i}-Y_{i}\right)^{2}}
$$

where $n$ is the total number of sample points and $X_{i}$ and $Y_{i}$ represent the observed and simulated values, respectively.

We used the bootstrapping method to provide confidence intervals necessary to determine whether these indicators (slopes, RMSE, and $R^{2}$ ) are different or not and repeated sampling for 4000 times in the bootstrapping analysis.

\subsection{Estimation of $\varepsilon_{\max }$}

The $\varepsilon_{\text {max }}$ is an important parameter in the GPP $\mathrm{MOD}_{\mathrm{M}}$ algorithm. The $\varepsilon_{\text {max }}$ for vegetation types can be obtained from an analysis of gross ecosystem exchange of $\mathrm{CO}_{2}$ and photosynthetic photon flux density (PPFD) at an eddy flux tower site [41,42]. In this study, we used a nonlinear model between GPP and PPFD (at half-hour time step) data to estimate the $\varepsilon_{\max }$ for each grassland site [43-45]. The abnormal observations (including zero values or extremely high values) have been excluded before fitting the function. The model is described below [42,43].

$$
N E E=\frac{\alpha \times P P F D \times G E E_{\max }}{\alpha \times P P F D-G E E_{\max }}-R
$$

where $\alpha$ is the apparent quantum yield and is assumed to be the $\varepsilon_{\max } . R$ is the ecosystem respiration, $G E E_{\text {max }}$ is the maximum gross ecosystem exchange (GEE), and NEE is the net ecosystem exchange.

\section{Results}

\subsection{Comparison of $G P P_{M O D}$ and $G P P_{E C}$}

Figure 2 illustrates the seasonal variation of $\mathrm{GPP}_{\mathrm{MOD}}$ and $\mathrm{GPP}_{\mathrm{EC}}$ at all sites. GPP $\mathrm{MOD}$ and $\mathrm{GPP}_{\mathrm{EC}}$ exhibit consistency in the magnitudes and seasonal variations at most of the grassland sites. GPP values started near zero in the winter, began to increase in the spring, reached its peak

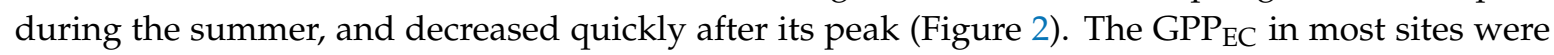
underestimated by the GPP $\mathrm{MOD}_{\text {. For example, the GPP }}$ EC were underestimated by $58.48 \%, 56.24 \%$, and 53.25\% in AT-Neu, RU-Sam, and IT-Tor, respectively (Figure 2a), ((1), and (j)). The coefficients of determination $\left(R^{2}\right)$ between $G P P_{\mathrm{MOD}}$ and GPP $\mathrm{EC}_{\mathrm{C}}$ varied from 0.17 (CI, 0.08-0.29) at the RU-Sam site to $0.83(0.77-0.89)$ at the DE-Gri site with all being statistically significant at $p<0.05$ (Figure 3) and all these analyses were tested with a 95\% confidence interval (Table 2). The linear regression between GPP ${ }_{\mathrm{MOD}}$ and GPP $\mathrm{EC}_{\mathrm{E}}$ showed that GPP $\mathrm{MOD}$ performed well at DE-Gri $\left(R^{2}=0.83(0.77-0.89)\right.$, $\left.R M S E=1.90(1.61-2.18) \mathrm{g} \mathrm{Cm}^{-2} \mathrm{day}^{-1}\right), \mathrm{CZ}-\mathrm{Bk} 2\left(R^{2}=0.82(0.74-0.88), R M S E=1.31(1.05-1.54)\right.$ $\mathrm{g} \mathrm{Cm}^{-2}$ day $\left.^{-1}\right)$, CH-Cha $\left(R^{2}=0.79(0.70-0.86), R M S E=3.64(3.29-4.00) \mathrm{g} \mathrm{Cm}^{-2} \mathrm{day}^{-1}\right), \mathrm{CH}-\mathrm{Fru}$ $\left(R^{2}=0.78(0.71-0.84), R M S E=3.19(2.78-3.57) \mathrm{g} \mathrm{Cm}^{-2} \mathrm{day}^{-1}\right)$, and AT-Neu $\left(R^{2}=0.78(0.72-0.83)\right.$, $R M S E=4.05(3.52-4.55) \mathrm{g} \mathrm{Cm}^{-2}$ day $\left.^{-1}\right)$, but it performed poor at RU-Sam $\left(R^{2}=0.17(0.08-0.29), R M S E\right.$ 
$\left.=0.89(0.74-1.03) \mathrm{g} \mathrm{Cm}^{-2} \mathrm{day}^{-1}\right)$, AU-Dap $\left(R^{2}=0.28(0.14-0.45), R M S E=3.31(2.88-3.70) \mathrm{g} \mathrm{Cm}^{-2}\right.$ day $\left.^{-1}\right)$, US-SRG $\left(R^{2}=0.40(0.18-0.59), R M S E=0.68(0.58-0.77) \mathrm{g} \mathrm{Cm}^{-2}\right.$ day $\left.^{-1}\right)$, and IT-Tor $\left(R^{2}=0.50\right.$ (0.33-0.67), RMSE $=2.81(2.23-3.34) \mathrm{g} \mathrm{Cm}^{-2} \mathrm{day}^{-1}$ ) (Figure 3). Moreover, GPP MOD had a $R^{2}$ of 0.66 (0.63-0.69) and RMSE of $2.46(2.33-2.58) \mathrm{g} \mathrm{Cm}^{-2} \mathrm{day}^{-1}$ for all grassland tower sites (Figure 4).
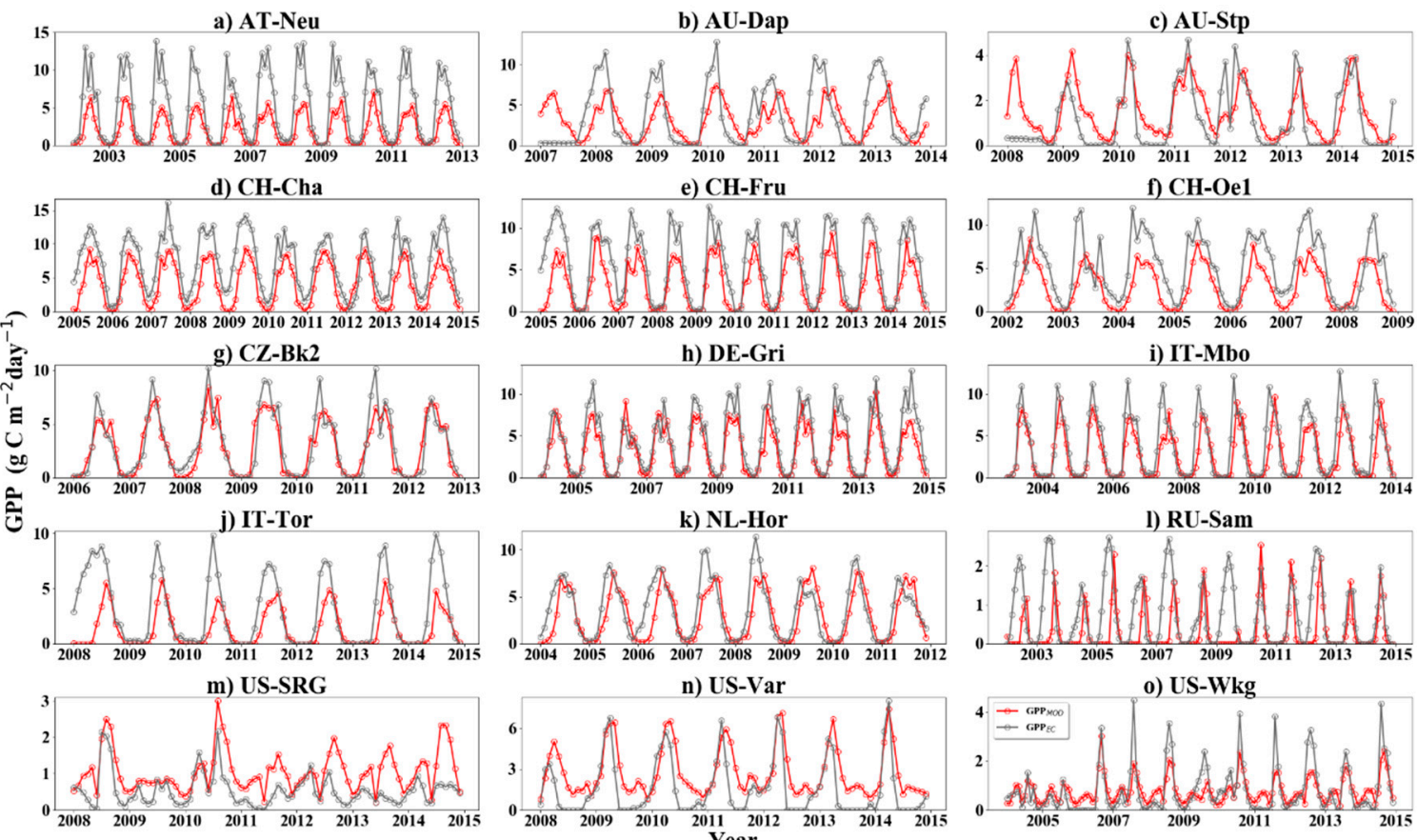
n) US-Var
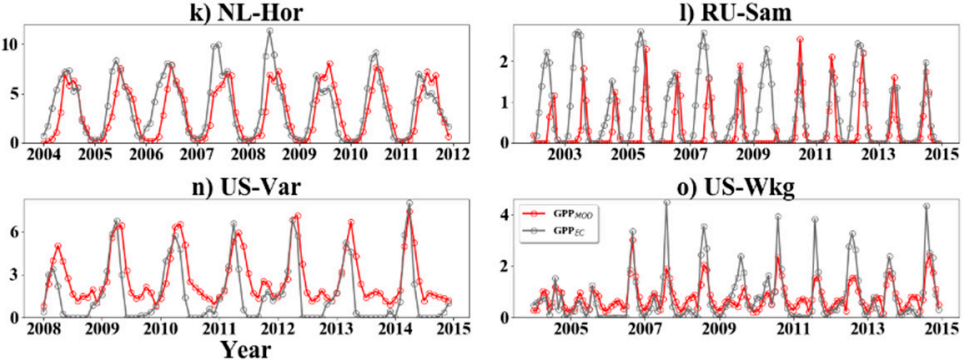

Figure 2. Seasonal variations of $\mathrm{GPP}_{\mathrm{MOD}}$ and observed $\mathrm{GPP}_{\mathrm{EC}}$ at all study sites.

Table 2. Statistics of the comparison between monthly GPP $\mathrm{MOD}_{\mathrm{D}}$ and $\mathrm{GPP}_{\mathrm{EC}}$ for all sites by using the linear regression model. The $95 \%$ confidence interval using the bootstrapping method is in parenthesis.

\begin{tabular}{cccc}
\hline Site ID & Slope & $\boldsymbol{R}^{2}$ & RMSE \\
\hline AT-Neu & $1.89(1.72,2.07)$ & $0.78(0.72,0.83)$ & $4.05(3.52,4.55)$ \\
AU-Dap & $0.92(0.60,1.24)$ & $0.28(0.14,0.45)$ & $3.31(2.88,3.70)$ \\
AU-Stp & $0.89(0.70,1.07)$ & $0.53(0.34,0.70)$ & $1.04(0.83,1.24)$ \\
CH-Cha & $1.14(1.03,1.25)$ & $0.79(0.70,0.86)$ & $3.64(3.29,4.00)$ \\
CH-Fru & $1.27(1.14,1.39)$ & $0.78(0.71,0.84)$ & $3.19(2.78,3.57)$ \\
CH-Oe1 & $1.14(0.94,1.34)$ & $0.61(0.48,0.74)$ & $3.19(2.72,3.66)$ \\
CZ-Bk2 & $1.04(0.93,1.15)$ & $0.82(0.74,0.88)$ & $1.31(1.05,1.54)$ \\
DE-Gri & $1.15(1.06,1.24)$ & $0.83(0.77,0.89)$ & $1.90(1.61,2.18)$ \\
IT-Mbo & $1.05(0.92,1.18)$ & $0.67(0.57,0.76)$ & $2.36(1.87,2.82)$ \\
IT-Tor & $1.30(1.01,1.58)$ & $0.50(0.33,0.67)$ & $2.81(2.23,3.34)$ \\
NL-Hor & $0.86(0.71,1.00)$ & $0.59(0.48,0.68)$ & $2.05(1.72,2.36)$ \\
RU-Sam & $0.58(0.37,0.79)$ & $0.17(0.08,0.29)$ & $0.89(0.74,1.03)$ \\
US-SRG & $0.50(0.37,0.63)$ & $0.40(0.18,0.59)$ & $0.68(0.58,0.77)$ \\
US-Var & $0.91(0.76,1.07)$ & $0.63(0.46,0.76)$ & $1.72(1.47,1.97)$ \\
US-Wkg & $1.59(1.41,1.77)$ & $0.70(0.61,0.78)$ & $0.63(0.49,0.75)$ \\
ALL & $1.22(1.18,1.26)$ & $0.66(0.63,0.69)$ & $2.46(2.33,2.58)$ \\
\hline
\end{tabular}



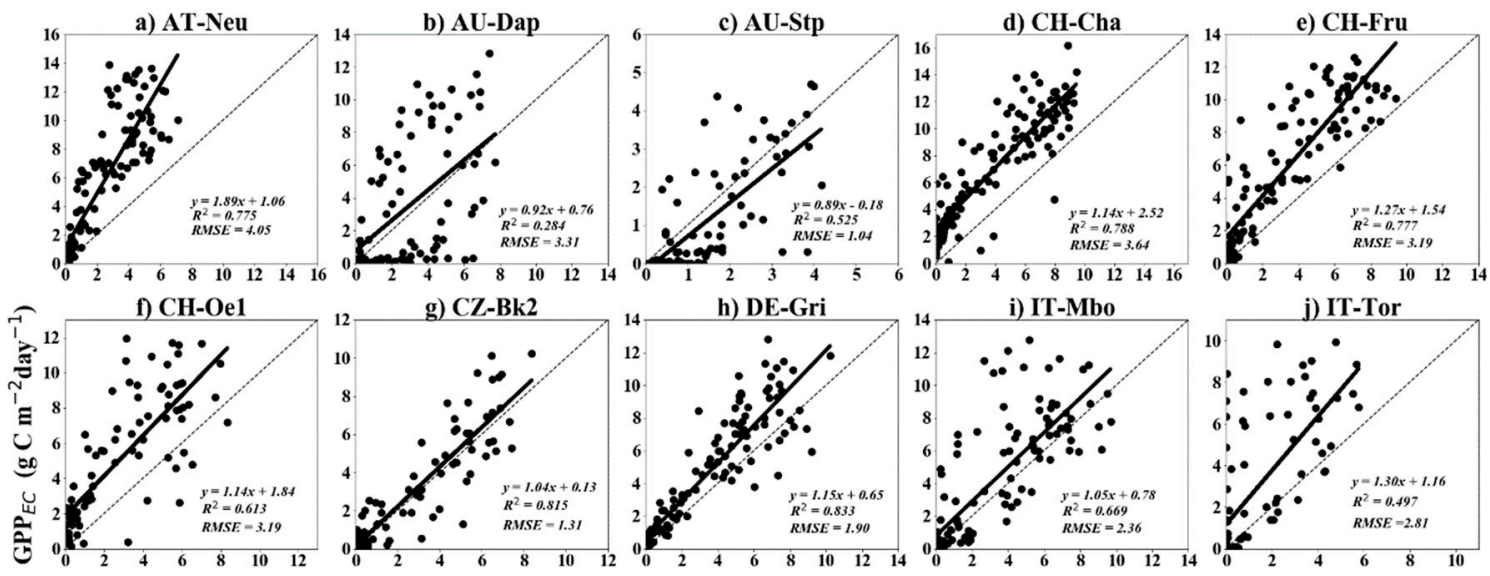

g) $\mathrm{CZ}-\mathrm{Bk} 2$

h) DE-Gri

i) IT-Mbo

j) IT-Tor
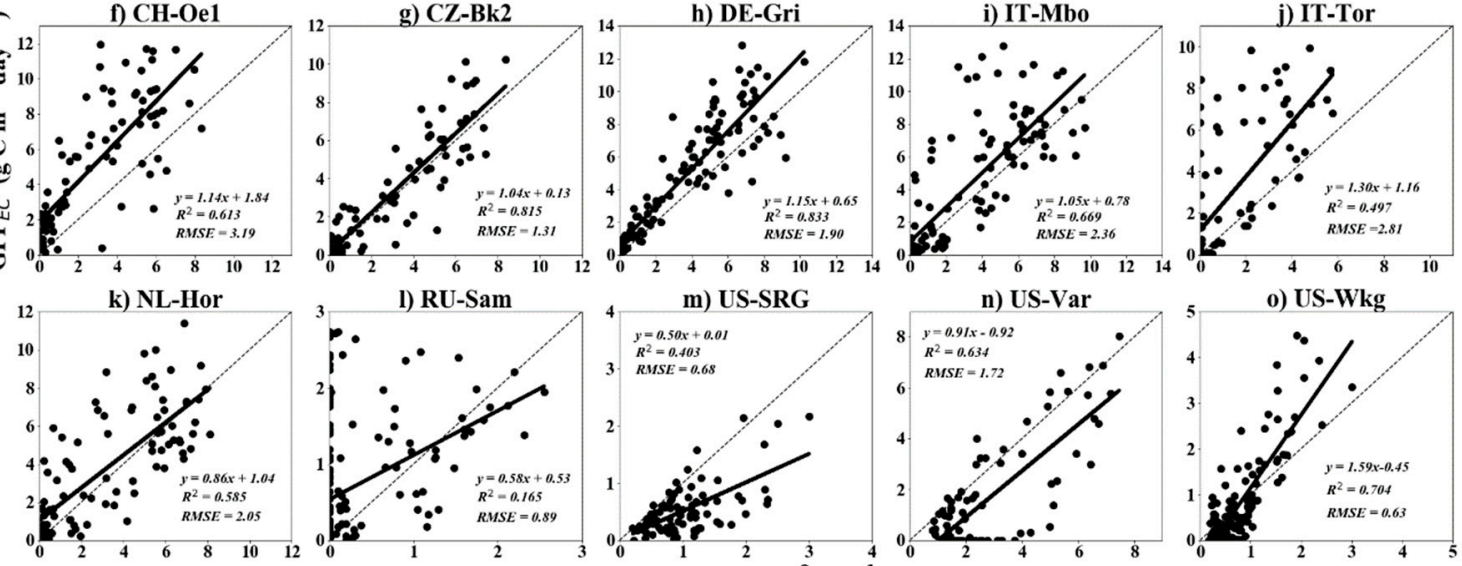

l) RU-Sam

m) US-SRG

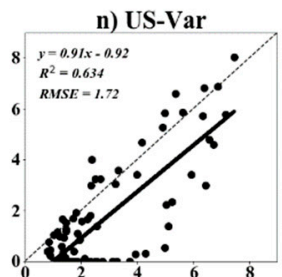

o) US-Wkg
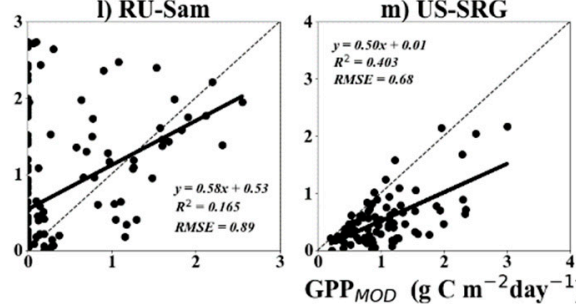

Figure 3. The relationship between $\mathrm{GPP}_{\mathrm{MOD}}$ and $\mathrm{GPP}_{\mathrm{EC}}$ for all sites. The short-dashed line is a 1:1 line. The unit of RMSE was $\mathrm{g} \mathrm{C} \mathrm{m}^{-2}$ day $^{-1}$.

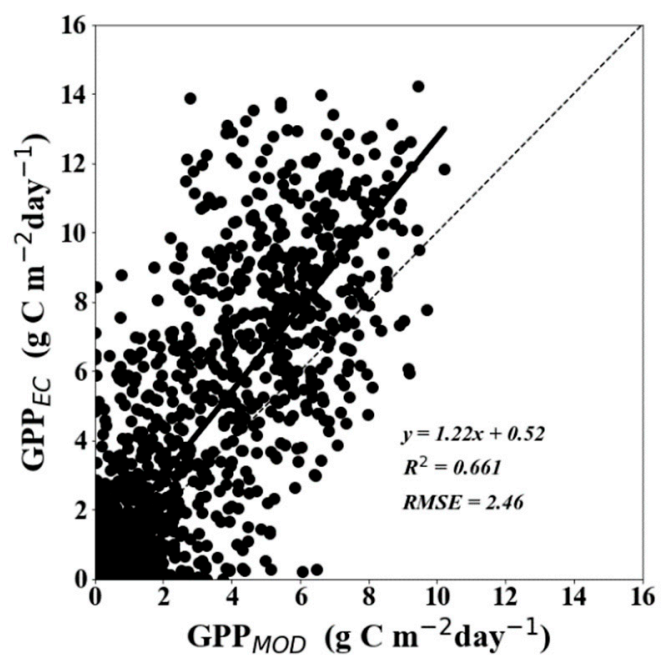

Figure 4. The relationship between $\mathrm{GPP}_{\mathrm{MOD}}$ and $\mathrm{GPP}_{\mathrm{EC}}$ for all sites. The short-dashed line is a 1:1 line.

The unit of RMSE was $\mathrm{g} \mathrm{C} \mathrm{m}^{-2}$ day $^{-1}$.

\subsection{Model Performances in Different Grassland Biomes}

We also considered the seasonal dynamic of $\mathrm{GPP}_{\mathrm{MOD}}$ by analyzing the relationship between $\mathrm{GPP}_{\mathrm{MOD}}$ and $\mathrm{GPP}_{\mathrm{EC}}$ within each grassland biome. The 15 flux sites were divided into three grassland biomes including the temperate, tropical, and alpine biomes. All analyses were tested with a 95\% confidence interval (Table 3). Figure 5 shows the different relationships between $\mathrm{GPP}_{\mathrm{EC}}$ and $\mathrm{GPP}_{\mathrm{MOD}}$ for each biome type. From Figure 5, we find GPP ${ }_{M O D}$ had better performance in a temperate grassland $\left(R^{2}=0.72(0.68-0.75), R M S E=2.40(2.25-2.54) \mathrm{g} \mathrm{Cm}^{-2}\right.$ day $\left.^{-1}\right)$ than an alpine grassland $\left(R^{2}=0.64\right.$ $(0.59-0.68), R M S E=2.55(2.30-2.79) \mathrm{g} \mathrm{Cm}^{-2}$ day $\left.^{-1}\right)$ or a tropical grassland $\left(R^{2}=0.40(0.27-0.52), R M S E\right.$ $=2.45(2.13-2.76) \mathrm{g} \mathrm{Cm}^{-2} \mathrm{day}^{-1}$ ) (Figure 5). Furthermore, MODIS GPP products underestimated GPP about $4 \%$ for the tropical grassland, $29 \%$ for the temperate grassland, and $41 \%$ for the alpine grassland, respectively. 
Table 3. Statistics regarding the comparison between $\mathrm{GPP}_{\mathrm{EC}}$ and $\mathrm{GPP}_{\mathrm{MOD}}$ for temperate, tropical, and alpine grassland biomes using a linear regression model. The $95 \%$ confidence interval derived by the bootstrapping method is in parenthesis.

\begin{tabular}{cccc}
\hline Grass Type & Slope & $\boldsymbol{R}^{\mathbf{2}}$ & RMSE \\
\hline Tropical grassland & $1.02(0.83,1.21)$ & $0.40(0.27,0.52)$ & $2.45(2.13,2.76)$ \\
Temperate grassland & $1.25(1.19,1.30)$ & $0.72(0.68,0.75)$ & $2.40(2.25,2.54)$ \\
Alpine grassland & $1.24(1.17,1.32)$ & $0.64(0.59,0.68)$ & $2.55(2.30,2.79)$ \\
\hline
\end{tabular}

a) Tropical

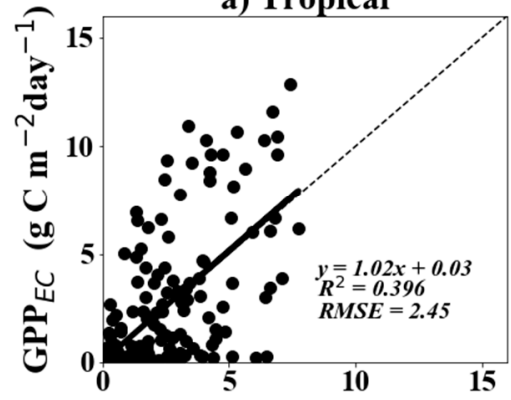

b) Temperate

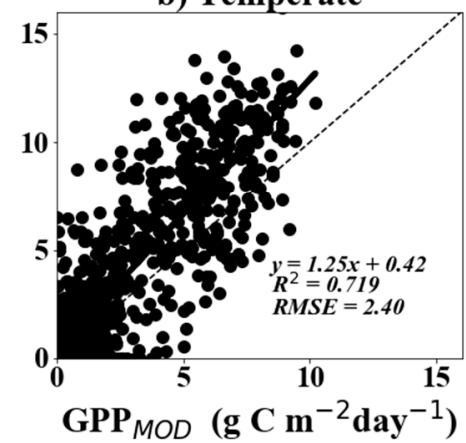

c) Alpine

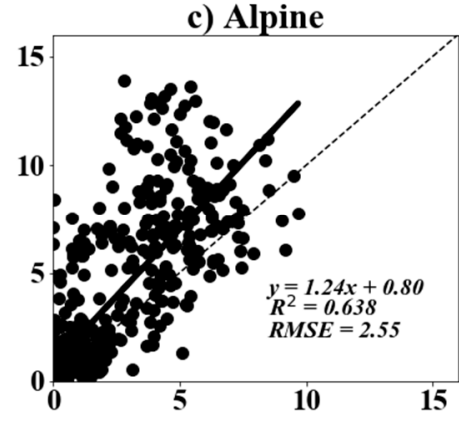

Figure 5. The relationships between $\mathrm{GPP}_{\mathrm{EC}}$ and $\mathrm{GPP}_{\mathrm{MOD}}$ for the temperate, tropical, and alpine grassland biomes. The short-dashed line is a 1:1 line. The unit of RMSE was $\mathrm{g} \mathrm{C}^{-2} \mathrm{day}^{-1}$.

\section{Discussion}

\subsection{Underestimation of MODIS GPP in Grasslands and Comparison with Previous Studies}

This study showed that GPP $\mathrm{MOD}$ had a promising ability to explain $\mathrm{GPP}_{\mathrm{EC}}$ variance $\left(R^{2}=0.66\right.$ (0.63-0.69) and RMSE $=2.46(2.33-2.58) \mathrm{g} \mathrm{Cm}^{-2}$ day $\left.^{-1}\right)$ at grassland sites, but GPP MOD consistently underestimated $\mathrm{GPP}_{\mathrm{EC}}$ (Figure 4). We also found that different grassland biomes had different performances. Specifically, GPP ${ }_{M O D}$ performed better in the temperate grassland sites than in the alpine and tropical grassland sites (Figure 5).

This study indicated that GPP MOD substantially underestimated GPP in grasslands, which agreed with previous studies [29-31]. For instance, Zhang [29] used GPP ${ }_{\mathrm{EC}}$ measurements to verify GPP $\mathrm{MOD}$ over an alpine meadow on the Tibetan Plateau, which further pointed out that MOD17 GPP products underestimated the mean annual GPP by $30 \%$ to $50 \%$. Turner et al. [46] also reported that GPP underestimated GPP at desert grassland sites. Xiao [47] evaluated GPP ${ }_{\mathrm{MOD}}$ by using GPP data from eddy covariance flux towers and their results showed that the GPP $\mathrm{MOD}$ products underestimated GPP by $45 \%$ at the Walnut Gulch Kendall grassland site. Despite the wide use of GPP ${ }_{M O D}$ to analyze inter-annual variation at regional scales in previous studies [48,49], the results from this study and the previously mentioned studies implied additional caution should be given when using GPP for inter-annual and intra-annual variation analyses of GPP in grasslands. We found that GPP underestimates observed GPP and that $\mathrm{GPP}_{\mathrm{MOD}}$ explained $66 \%(63 \%-69 \%)$ of the variance in $\mathrm{GPP}_{\mathrm{EC}}$ $\left(R^{2}=0.66(0.63-0.69), R M S E=2.46(2.33-2.58) \mathrm{g} \mathrm{Cm}^{-2}\right.$ day $\left.^{-1}\right)$.

In addition, we found that the GPP $\mathrm{MOD}$ could explain more GPP variance for the temperate and alpine grassland sites than for the tropical grassland sites (Figure 5). Thus, GPP $\mathrm{POD}_{\mathrm{MOD}}$ performed better in lower GPP situations (e.g., drought condition and temperate grassland biome), which further illustrated that the GPP ${ }_{\mathrm{MOD}}$ tended to underestimate GPP.

\subsection{Attributing Underestimation in Grassland GPP and Its Implications}

In this study, $\mathrm{GPP}_{\mathrm{MOD}}$ explained $\mathrm{GPP}_{\mathrm{EC}}$ by $72 \%(68 \%-75 \%)$ at temperate grassland sites, $64 \%$ $(59 \%-68 \%)$ at alpine grassland sites, and $40 \%(27 \%-52 \%)$ at tropical grassland sites (Figure 5). Potential 
reasons for the uncertainty in MODIS GPP products could be due to different factors such as maximum LUE, meteorological data, FPAR, and land cover/vegetation types [50].

These varied performances may be related to the maximum light use efficiency $\left(\varepsilon_{\max }\right)$ [51]. For the MODIS GPP algorithm, $\varepsilon_{\max }$ was determined by using the Biome Properties Look-Up (BPLUT) for given biome types, which was for $0.86 \mathrm{~g} \mathrm{C} \mathrm{MJ}^{-1}$ grass [38]. The underestimated $\varepsilon_{\max }$ values could be the major reason for underestimates of GPP in the grasslands [51]. Based on the nonlinear model (Equation (6)), we estimated the $\varepsilon_{\max }$ for each grassland site in this study (Table 4). In most sites (except for AU-Stp, US-SRG, and US-Var), the estimated values of $\varepsilon_{\max }$ were larger than that used in the MOD17 GPP algorithm, which can partly explain the underestimation of the MODIS GPP in these grassland sites. Moreover, when the $\varepsilon_{\max }$ used in the MOD17 GPP algorithm ( $\varepsilon_{\max }$-BPLUT) were simply replaced with the estimated $\varepsilon_{\max }\left(\varepsilon_{\max }\right.$-EST), the RMSEs were smaller than before (except for the site of CZ-Bk2) (Figure 6). This demonstrated that the $\varepsilon_{\max }$ have an important influence on the result of the GPP estimation based on the MOD17 GPP algorithm. Previous studies have also suggested different $\varepsilon_{\max }$ for different grassland biomes. For example, $1.31 \mathrm{~g} \mathrm{C} \mathrm{MJ}^{-1}$ for alpine grassland and $1.21 \mathrm{~g} \mathrm{C} \mathrm{MJ}^{-1}$ for tropical grassland [52,53]. Sjöström et al. [27] increased $\varepsilon_{\max }$ for grasslands from $0.86 \mathrm{~g} \mathrm{C} \mathrm{MJ}^{-1}$ to $2.01 \mathrm{~g} \mathrm{C} \mathrm{MJ}^{-1}$, which improved the ability for GPP $\mathrm{MOD}$ to explain the variance of $\mathrm{GPP}_{\mathrm{EC}}$ from $25 \%$ to $74 \%$.

Table 4. The comparison of the $\varepsilon_{\max }$ between the estimated values based on the nonlinear model $\left(\varepsilon_{\max }\right.$-EST) and the values in the biome properties look-up table $\left(\varepsilon_{\max }\right.$-BPLUT) used in the MOD17 GPP algorithm. "RMSE after" and "RMSE before" referred to the RMSE between the GPP EC $_{\text {and GPP }}$ MOD with $\varepsilon_{\text {max }}$-EST and $\varepsilon_{\text {max }}$-BPLUT, respectively.

\begin{tabular}{cccccc}
\hline Site ID & $\begin{array}{c}\varepsilon_{\text {max }} \text {-EST } \\
\text { g C/MJ }\end{array}$ & $\begin{array}{c}\varepsilon_{\text {max }} \text {-BPLUT } \\
\text { g C/MJ }\end{array}$ & $\begin{array}{c}\text { RMSE After } \\
\mathbf{g ~ C m}^{-2} \mathbf{d a y}^{-\mathbf{1}}\end{array}$ & $\begin{array}{c}\text { RMSE Before } \\
\mathbf{g ~ C m}^{-2} \text { day }^{-1}\end{array}$ & $\begin{array}{c}\varepsilon_{\text {max }} \text { bias } \\
\text { g C/MJ }\end{array}$ \\
\hline AT-Neu & 1.71 & 0.86 & 2.30 & 4.05 & 0.85 \\
AU-Dap & 0.87 & 0.86 & 3.30 & 3.31 & 0.01 \\
AU-Stp & 0.73 & 0.86 & 0.98 & 1.04 & -0.13 \\
CH_Cha & 0.97 & 0.86 & 3.19 & 3.64 & 0.11 \\
CH-Fru & 1.28 & 0.86 & 2.24 & 3.19 & 0.42 \\
CH-Oe1 & 1.13 & 0.86 & 2.64 & 3.19 & 0.27 \\
CZ-Bk2 & 2.57 & 0.86 & 7.42 & 1.31 & 1.71 \\
DE-Gri & 1.09 & 0.86 & 1.53 & 1.90 & 0.23 \\
IT-Mbo & 0.98 & 0.86 & 2.24 & 2.36 & 0.12 \\
IT-Tor & 1.13 & 0.86 & 2.55 & 2.81 & 0.27 \\
NL-Hor & 0.93 & 0.86 & 2.04 & 2.05 & 0.07 \\
RU-Sam & 0.93 & 0.86 & 0.89 & 0.89 & 0.07 \\
US-SRG & 0.77 & 0.86 & 0.57 & 0.68 & -0.09 \\
US-Var & 0.76 & 0.86 & 1.52 & 1.72 & -0.10 \\
US-Wkg & 1.07 & 0.86 & 0.60 & 0.63 & 0.21 \\
\hline
\end{tabular}

There are also potential uncertainties from FPAR, which could affect the accuracy of GPP ${ }_{M O D}$.

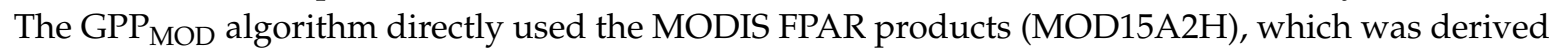
from a radiative transfer model. The MODIS FPAR usually overestimated the "green" FPAR with a positive offset for barren land and was saturated at high GPP values. This behavior further affected $\varepsilon$ and GPP estimation [54]. In this study, GPP ${ }_{\mathrm{MOD}}$ underestimated $\mathrm{GPP}_{\mathrm{EC}}$ for grassland ecosystems, which may be caused by the uncertainty of FPAR and the methods used to simulate FPAR. For example, Liu et al. [55] used a three-dimensional formulation of the radiative transfer process in the canopy and assessed FPAR $R_{\text {canopy }}$ performances of scaled EVI (FPAR chl1 $\left._{1}\right)$, NDVI, scaled NDVI (FPAR chl2), and EVI. The results showed that the FPAR canopy $_{\text {of scaled EVI }}\left(\mathrm{FPAR}_{\text {chl }}\right)$ improved the accuracy of GPP $\mathrm{MOD}$ for grasslands. 

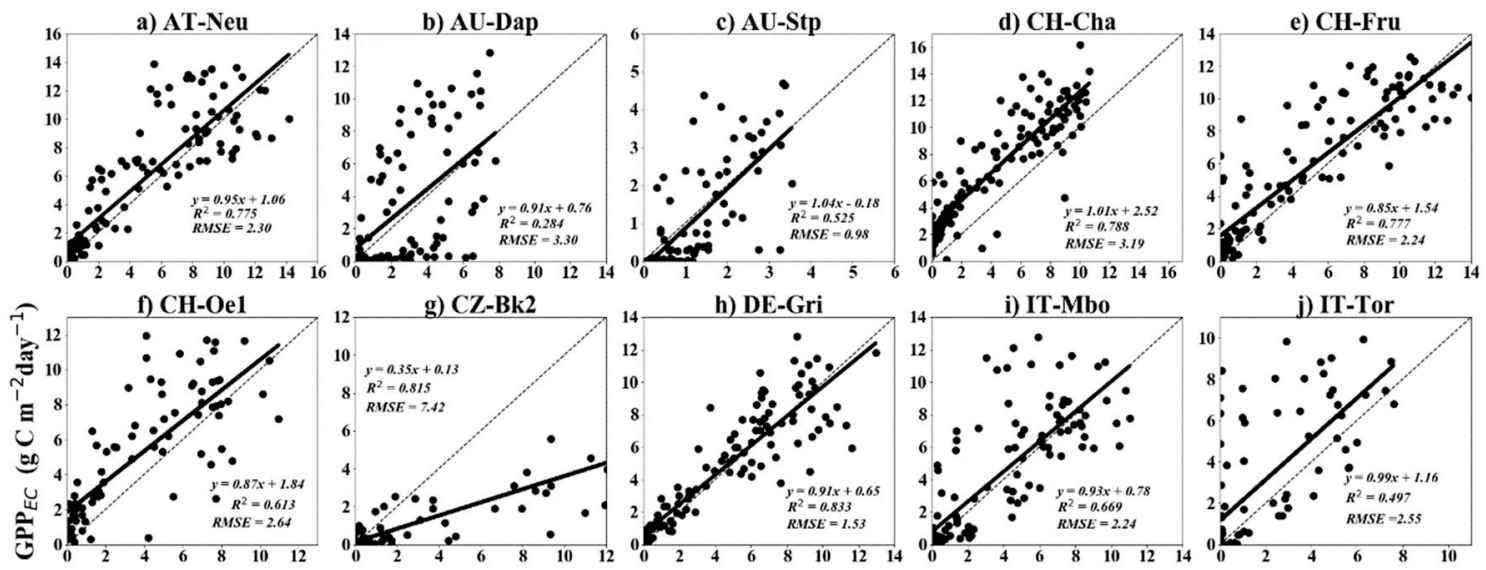

g) $\mathrm{CZ}-\mathrm{Bk} 2$

h) DE-Gri

i) IT-Mbo

j) IT-Tor
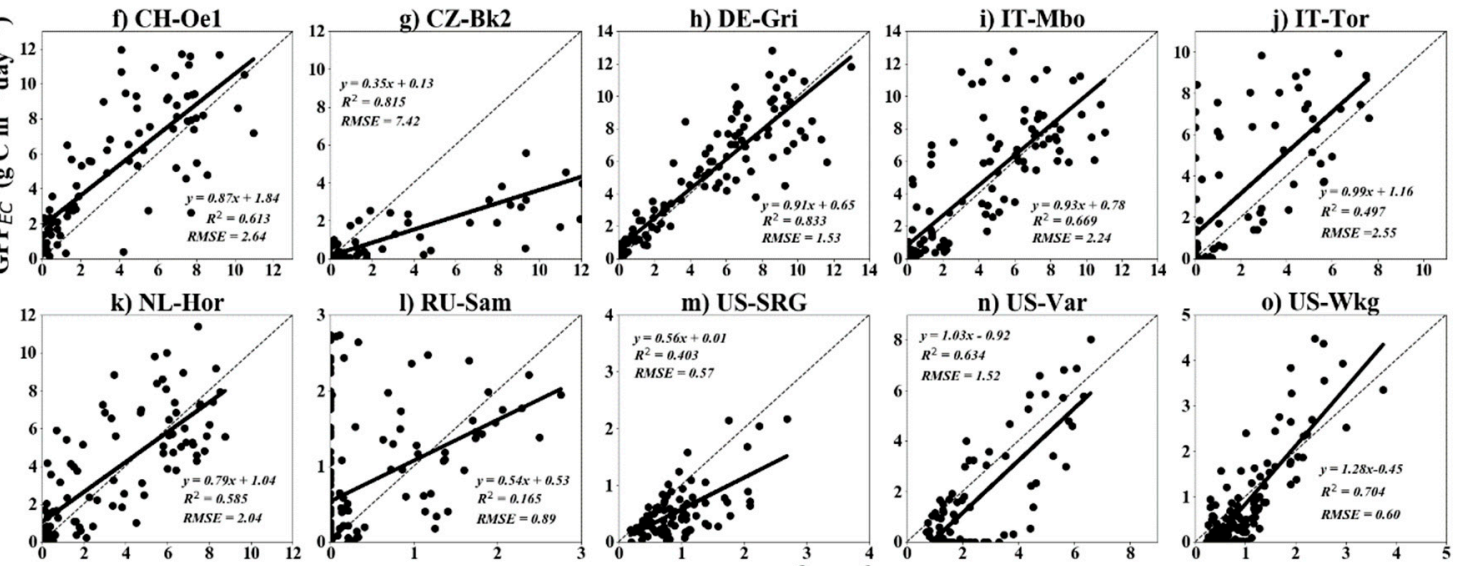

l) RU-Sam
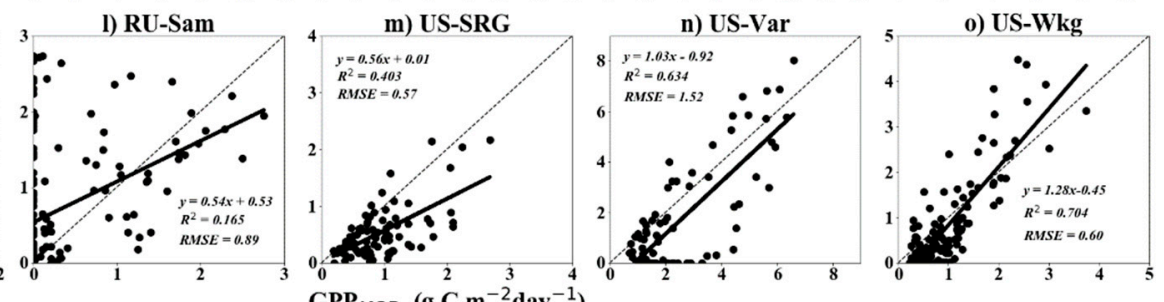

Figure 6. The relationship between $\mathrm{GPP}_{\mathrm{MOD}}$ and $\mathrm{GPP} \mathrm{EC}_{\mathrm{EC}}$ for all sites with the $\varepsilon_{\max }\left(\varepsilon_{\max }\right.$-BPLUT) used in the MOD17 GPP algorithm was replaced by the estimated $\varepsilon_{\max }\left(\varepsilon_{\max }\right.$-EST). The unit of RMSE was $\mathrm{g} \mathrm{C} \mathrm{m}^{-2}$ day $^{-1}$.

Another previous study [55] compared MODIS-FPAR and GLASS-FPAR (derived from the product of the Global Land Surface Satellite (GLASS)). MODIS-FPAR performed well with a higher $R^{2}$ and a lower bias for mixed forests and cropland. However, GLASS-FPAR performed better in grasslands with a higher $R^{2}$ and a lower bias [55]. Furthermore, Kucharik et al. [33] and Wu et al. [51] pointed out that the adaptive Savitzky-Golay filtered FPAR data could have better performance compared with the FPAR data based on the linear interpolation approach used in the MODIS algorithm. The adaptive SG method could maintain some intrinsic seasonal variability and keep reliable values of FPAR. Further uncertainties also arise due to the canopy photosynthesis saturation effects on the FPAR [56]. In this study, GPP $\mathrm{MOD}$ products underestimated GPP in tropical grassland sites because of the saturation of canopy photosynthesis. A previous study showed that the MODIS light use efficiency approach does not account for saturation of canopy photosynthesis under clear sky conditions in a tropical forest site [50]. Saturation can result in the underestimation of GPP with low values of FPAR but overestimation with high FPAR values [50]. The tropical grassland received solar radiation for extended periods and it was easy for canopy photosynthesis saturation to occur [57] especially in periods of drought. Previous studies also reported that saturation of canopy photosynthesis might occur on clear-sky days at the hourly and daily timescales $[25,58,59]$.

The species composition of grassland ecosystems could also cause uncertainty in GPP estimates. Grasslands are dynamic ecosystems that often have diverse mixtures of $C 3$ and C4 species, which have different light use efficiencies. Furthermore, the ratio of $\mathrm{C} 3$ and $\mathrm{C} 4$ species within a grassland can have high intra-annual and inter-annual variability [31]. Such community composition data is not available for all the FLUXNET sites. The effects of the composition of C3 and C4 grasses on GPP simulation is an interesting question, but it is beyond the scope of this specific study. However, a recent GPP product considering the C3 and C4 photosynthesis pathways showed improved performances in grassland ecosystems [60]. The water stress scalar could also have uncertainty when using VPD as a proxy of water stress in the PSN model. To decrease uncertainties, we suggest using long-term meteorological observation data or remote sensing-based water stress indicators [61] to quantify the water stress scalar especially in drought conditions. Furthermore, fundamental improvements could 


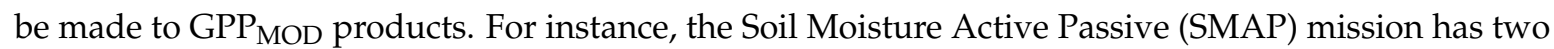
to three day temporal fidelity and an enhanced $(\leq 9 \mathrm{~km})$ spatial resolution that provide accurate global mapping of the freeze-thaw state and the surface soil moisture [62].

\subsection{Model Performances under Drought and Non-Drought Conditions}

$\mathrm{GPP}_{\mathrm{MOD}}$ could have different performances under drought conditions. We used the Standardized Precipitation Index (SPI) to identify the periods of drought. The SPI is designed to be a spatially invariant indicator of drought, which recognizes the importance of time scale in the analysis of water use [63]. In this study, the precipitation from the FluxNet sites was used to calculate SPI for each month to determine the status of drought [64]. If SPI was less than -0.5, it was defined as drought [65]. We analyzed the relationships between monthly GPP ${ }_{\mathrm{MOD}}$ and GPP $\mathrm{EC}$ in both non-drought and drought conditions. The results showed that GPP $\mathrm{MOD}$ had higher $R^{2}(0.72(0.66-0.79))$ and lower $R M S E$ (2.33 (2.05-2.60) $\mathrm{g} \mathrm{Cm}^{-2}$ day $\left.^{-1}\right)$ in drought conditions than in non-drought conditions with lower $R^{2}$ (0.64 (0.61-0.68)) and higher RMSE (2.48 (2.34-2.62) $\mathrm{g} \mathrm{Cm}^{-2}$ day $^{-1}$ ), which indicates that GPP ${ }_{\text {MOD had }}$ better explanatory capabilities for $\mathrm{GPP}_{\mathrm{EC}}$ variances under drought conditions than under non-drought conditions (Table A1).

Although several studies have reported that the standard MODIS GPP products did not accurately estimate carbon uptake during drought conditions [24,66,67]. The role of VPD in determining GPP has been examined [68]. For example, Turner et al. [46] pointed out that a high VPD scalar could reduce GPP values during a dry period. Another study also found that VPD had a weak positive correlation with GPP. Furthermore, VPD sometimes failed to capture drought events [69]. In this study, however, it is notable that $\mathrm{GPP}_{\mathrm{MOD}}$ had a better performance in drought conditions than in non-drought conditions for grasslands.

We analyzed the relationships between the VPD-based water scalar and GPP ${ }_{M O D}$ and found a higher $R^{2}$ between GPP and VPD-based water scaler in drought conditions (Figure 7) even though they had weak correlations in both drought and non-drought conditions $(26 \%$ vs. $8 \%$, Figure $7 \mathrm{~b}, \mathrm{c})$. The MOD17A2H GPP products of grassland have better performance in drought conditions, which could be attributed to the $W_{\text {scalar }}$. However, there could be some uncertainty in the drought identification since SPI calculation was based on a short-term precipitation record in some sites. More studies are still needed in the future for a thorough analyses. The weak correlation between $\mathrm{W}_{\text {scalar }}$ and GPP suggest that the water scalar could be further improved in the grasslands.

a) All

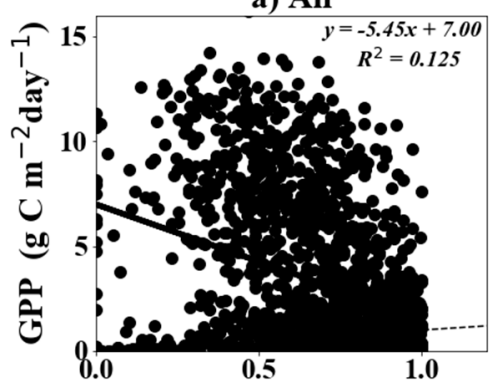

b) Drought

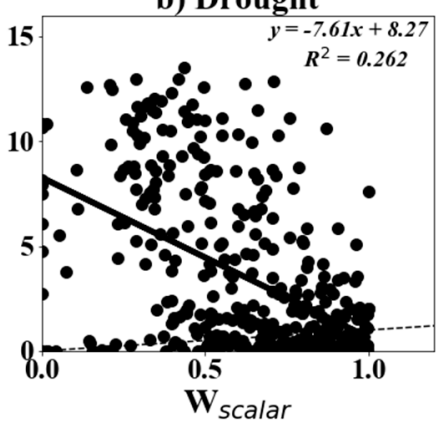

c) Non-drought

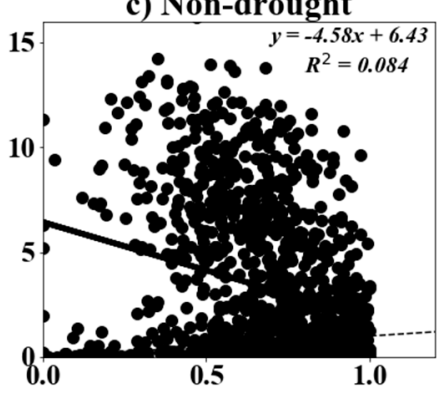

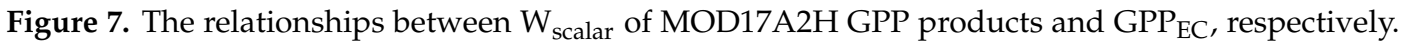
The solid line is a linear regression. The short-dashed line is a 1:1 line.

\section{Conclusions}

The GPP of grassland ecosystems plays a vital role in carbon sequestration, food production, and biodiversity [70]. In this study, we investigated and evaluated the performance and robustness of GPP ${ }_{M O D}$ at grassland sites across the globe. We found that: (1) GPP eddy covariance sites suggested a high explanation capability of GPP variances (66\%) but GPP 
generally underestimated GPP about $34 \%$ for grassland ecosystems. (2) $\mathrm{GPP}_{\mathrm{MOD}}$ performed better for the temperate grassland $\left(R^{2}=0.72(0.68-0.75), R M S E=2.40(2.25-2.54) \mathrm{g} \mathrm{Cm}^{-2}\right.$ day $\left.^{-1}\right)$ than the alpine $\left(R^{2}=0.64(0.59-0.68), R M S E=2.55(2.30-2.79) \mathrm{g} \mathrm{Cm}^{-2}\right.$ day $\left.^{-1}\right)$ and the tropical grasslands $\left(R^{2}=0.40\right.$ $(0.27-0.52), R M S E=2.45(2.13-2.76) \mathrm{g} \mathrm{Cm}^{-2}$ day $\left.^{-1}\right)$. The inconsistent underestimates of GPP $\mathrm{MOD}$ for the three grassland biomes may be rooted in the MODIS GPP algorithm, which underestimated $\varepsilon_{\max }$ for the different grassland biomes. The varied performances of the GPP standard products in different grassland types implied that the parameterization of the MOD17A2H GPP products (e.g., $\varepsilon_{\max }$, FPAR, and water scalar) could be improved to better capture changes in GPP.

Author Contributions: Conceptualization, Z.X., J.D. and Z.Z.; Methodology, Z.X., Y.P. and Y.Z.; Software, Z.X., Y.P., Y.Z. and G.Z.; Validation, Z.X. and Y.P.; Formal Analysis, Y.P. and Z.X.; Data Curation, X.X.; Writing-Original Draft Preparation, Z.X.; Writing-Review \& Editing, Y.P., J.D. and Z.X.; Supervision, Y.Z., J.B., L.C., R.B.D., G.Z. and X.X.

Funding: This research was funded by the Strategic Priority Research Program (XDA19040301), the Key Research Program of Frontier Sciences (QYZDB-SSW-DQC005) of the Chinese Academy of Sciences (CAS), and the "Thousand Youth Talents Plan".

Conflicts of Interest: The authors declare no conflict of interest.

\section{Appendix A}

Table A1. The relationship between $\mathrm{GPP}_{\mathrm{EC}}$ and $\mathrm{GPP}_{\mathrm{MOD}}$ for the temperate, tropical, and alpine grassland biomes in both non-drought and drought conditions. The $95 \%$ confidence interval using the bootstrapping method is in parenthesis.

\begin{tabular}{ccccc}
\hline & Type & Slope & $\boldsymbol{R}^{\mathbf{2}}$ & RMSE \\
\hline \multirow{4}{*}{ Drought } & Tropical grassland & $1.05(0.26,1.85)$ & $0.37(0.01,0.86)$ & $3.55(2.39,4.49)$ \\
conditions & Temperate grassland & $1.22(1.12,1.32)$ & $0.79(0.73,0.85)$ & $2.14(1.86,2.42)$ \\
& Alpine grassland & $1.20(1.04,1.36)$ & $0.68(0.57,0.78)$ & $2.36(1.83,2.84)$ \\
& ALL & $1.19(1.10,1.28)$ & $0.72(0.66,0.79)$ & $2.33(2.05,2.60)$ \\
\hline \multirow{2}{*}{ Non-drought } & Tropical grassland & $1.01(0.81,1.20)$ & $0.40(0.28,0.54)$ & $2.31(1.99,2.62)$ \\
conditions & Temperate grassland & $1.26(1.20,1.32)$ & $0.70(0.66,0.74)$ & $2.45(2.28,2.61)$ \\
& Alpine grassland & $1.26(1.17,1.35)$ & $0.63(0.58,0.68)$ & $2.59(2.32,2.87)$ \\
& ALL & $1.23(1.18,1.28)$ & $0.65(0.61,0.68)$ & $2.48(2.34,2.62)$ \\
\hline
\end{tabular}

\section{References}

1. Beer, C.; Reichstein, M.; Tomelleri, E.; Ciais, P.; Jung, M.; Carvalhais, N.; Rodenbeck, C.; Arain, M.A.; Baldocchi, D.; Bonan, G.B.; et al. Terrestrial Gross Carbon Dioxide Uptake: Global Distribution and Covariation with Climate. Science 2010, 329, 834-838. [CrossRef] [PubMed]

2. Kotchenova, S.Y.; Song, X.; Shabanov, N.V.; Potter, C.S.; Knyazikhin, Y.; Myneni, R.B. Lidar Remote Sens. for modeling gross primary production of deciduous forests. Remote Sens. Environ. 2004, 92, 158-172. [CrossRef]

3. Falge, E. Seasonality of ecosystem respiration and gross primary production as derived from FLUXNET measurements. Agric. For. Meteorol. 2002, 113, 53-74. [CrossRef]

4. Zhou, L.; He, H.-L.; Sun, X.-M.; Zhang, L.; Yu, G.-R.; Ren, X.-L.; Wang, J.-Y.; Zhao, F.-H. Modeling winter wheat phenology and carbon dioxide fluxes at the ecosystem scale based on digital photography and eddy covariance data. Ecol. Inform. 2013, 18, 69-78. [CrossRef]

5. Che, M.; Chen, B.; Innes, J.L.; Wang, G.; Dou, X.; Zhou, T.; Zhang, H.; Yan, J.; Xu, G.; Zhao, H. Spatial and temporal variations in the end date of the vegetation growing season throughout the Qinghai-Tibetan Plateau from 1982 to 2011. Agric. For. Meteorol. 2014, 189, 81-90. [CrossRef]

6. Han, Q. Modeling the grazing effect on dry grassland carbon cycling with Biome-BGC model. Ecol. Complex. 2014, 17, 149-157. [CrossRef]

7. Zhang, Y.; Xiao, X.; Guanter, L.; Zhou, S.; Ciais, P.; Joiner, J.; Sitch, S.; Wu, X.; Nabel, J.; Dong, J.; et al. Precipitation and carbon-water coupling jointly control the interannual variability of global land gross primary production. Sci. Rep. 2016, 6, 39748. [CrossRef] [PubMed] 
8. Singh, R.P.; Rovshan, S.; Goroshi, S.K.; Panigrahy, S.; Parihar, J.S. Spatial and Temporal Variability of Net Primary Productivity (NPP) over Terrestrial Biosphere of India Using NOAA-AVHRR Based GloPEM Model. J. Indian Soc. Remote Sens. 2011, 39, 345-353. [CrossRef]

9. Yuan, J.; Niu, Z.; Wang, C. Vegetation NPP distribution based on MODIS data and CASA model-A case study of northern Hebei Province. Chin. Geogr. Sci. 2006, 16, 334-341. [CrossRef]

10. Xiao, X.; Zhang, Q.; Saleska, S.; Hutyra, L.; De Camargo, P.; Wofsy, S.; Frolking, S.; Boles, S.; Keller, M.; Moore, B. Satellite-based modeling of gross primary production in a seasonally moist tropical evergreen forest. Remote Sens. Environ. 2005, 94, 105-122. [CrossRef]

11. Zhang, Y.; Xiao, X.; Jin, C.; Dong, J.; Zhou, S.; Wagle, P.; Joiner, J.; Guanter, L.; Zhang, Y.; Zhang, G.; et al. Consistency between sun-induced chlorophyll fluorescence and gross primary production of vegetation in North America. Remote Sens. Environ. 2016, 183, 154-169. [CrossRef]

12. Ito, A. The regional carbon budget of East Asia simulated with a terrestrial ecosystem model and validated using AsiaFlux data. Agric. For. Meteorol. 2008, 148, 738-747. [CrossRef]

13. Malciute, A.; Naujalis, J.R.; Sauliene, I. The seasonal development characteristics of different taxa and cultivars of rhododendrons in Northern Lithuania. 2. Flowering peculiarities. Zemdirb.-Agric. 2011, 98, 81-92.

14. Running, S.W.; Nemani, R.R.; Heinsch, F.A.; Zhao, M.S.; Reeves, M.; Hashimoto, H. A continuous satellite-derived measure of global terrestrial primary production. Bioscience 2004, 54, 547-560. [CrossRef]

15. Wang, H.; Jia, G.; Fu, C.; Feng, J.; Zhao, T.; Ma, Z. Deriving maximal light use efficiency from coordinated flux measurements and satellite data for regional gross primary production modeling. Remote Sens. Environ. 2010, 114, 2248-2258. [CrossRef]

16. Horn, J.E.; Schulz, K. Spatial extrapolation of light use efficiency model parameters to predict gross primary production. J. Adv. Model. Earth Syst. 2011, 3. [CrossRef]

17. Yuan, W.; Cai, W.; Xia, J.; Chen, J.; Liu, S.; Dong, W.; Merbold, L.; Law, B.; Arain, A.; Beringer, J.; et al. Global comparison of light use efficiency models for simulating terrestrial vegetation gross primary production based on the LaThuile database. Agric. For. Meteorol. 2014, 192, 108-120. [CrossRef]

18. Yuan, W.; Chen, Y.; Xia, J.; Dong, W.; Magliulo, V.; Moors, E.; Olesen, J.E.; Zhang, H. Estimating crop yield using a satellite-based light use efficiency model. Ecol. Indic. 2016, 60, 702-709. [CrossRef]

19. Zhang, Y.; Xiao, X.; Zhou, S.; Ciais, P.; McCarthy, H.; Luo, Y. Canopy and physiological controls of GPP during drought and heat wave. Geophys. Res. Lett. 2016, 43, 3325-3333. [CrossRef]

20. Zhang, Y.; Xu, M.; Chen, H.; Adams, J. Global pattern of NPP to GPP ratio derived from MODIS data: Effects of ecosystem type, geographical location and climate. Glob. Ecol. Biogeogr. 2009, 18, 280-290. [CrossRef]

21. Xia, J.; Niu, S.; Ciais, P.; Janssens, I.A.; Chen, J.; Ammann, C.; Arain, A.; Blanken, P.D.; Cescatti, A.; Bonal, D.; et al. Joint control of terrestrial gross primary productivity by plant phenology and physiology. Proc. Natl. Acad. Sci. USA 2015, 112, 2788-2793. [CrossRef] [PubMed]

22. Zhao, M.; Heinsch, F.A.; Nemani, R.R.; Running, S.W. Improvements of the MODIS terrestrial gross and net primary production global data set. Remote Sens. Environ. 2005, 95, 164-176. [CrossRef]

23. Sims, D.; Rahman, A.; Cordova, V.; Elmasri, B.; Baldocchi, D.; Bolstad, P.; Flanagan, L.; Goldstein, A.; Hollinger, D.; Misson, L. A new model of gross primary productivity for North American ecosystems based solely on the enhanced vegetation index and land surface temperature from MODIS. Remote Sens. Environ. 2008, 112, 1633-1646. [CrossRef]

24. Coops, N.; Black, T.; Jassal, R.; Trofymow, J.; Morgenstern, K. Comparison of MODIS, eddy covariance determined and physiologically modelled gross primary production (GPP) in a Douglas-fir forest stand. Remote Sens. Environ. 2007, 107, 385-401. [CrossRef]

25. Turner, D.P.; Ritts, W.D.; Cohen, W.B.; Gower, S.T.; Zhao, M.; Running, S.W.; Wofsy, S.C.; Urbanski, S.; Dunn, A.L.; Munger, J.W. Scaling Gross Primary Production (GPP) over boreal and deciduous forest landscapes in support of MODIS GPP product validation. Remote Sens. Environ. 2003, 88, 256-270. [CrossRef]

26. Leuning, R.; Cleugh, H.A.; Zegelin, S.J.; Hughes, D. Carbon and water fluxes over a temperate Eucalyptus forest and a tropical wet/dry savanna in Australia: Measurements and comparison with MODIS Remote Sens. estimates. Agric. For. Meteorol. 2005, 129, 151-173. [CrossRef]

27. Sjöström, M.; Zhao, M.; Archibald, S.; Arneth, A.; Cappelaere, B.; Falk, U. Evaluation of MODIS gross primary productivity for Africa using eddy covariance data. Remote Sens. Environ. 2013, 131, 275-286. [CrossRef] 
28. Running, S.W.; Maosheng, Z. User's Guide Daily GPP and Annual NPP (MOD17A2/A3) Products NASA Earth Observing System MODIS Land Algorithm; The Numerical Terradynamic Simulation Group: Missoula, MT, USA, 2015.

29. Zhang, Y.; Yu, Q.; Jiang, J.I.E.; Tang, Y. Calibration of Terra/MODIS gross primary production over an irrigated cropland on the North China Plain and an alpine meadow on the Tibetan Plateau. Glob. Chang. Biol. 2008, 14, 757-767. [CrossRef]

30. Zhu, H.; Lin, A.; Wang, L.; Xia, Y.; Zou, L. Evaluation of MODIS Gross Primary Production across Multiple Biomes in China Using Eddy Covariance Flux Data. Remote Sens. 2016, 8, 395. [CrossRef]

31. Doughty, R.; Xiao, X.; Wu, X.; Zhang, Y.; Bajgain, R.; Zhou, Y.; Qin, Y.; Zou, Z.; McCarthy, H.; Friedman, J.; et al. Responses of gross primary production of grasslands and croplands under drought, pluvial, and irrigation conditions during 2010-2016, Oklahoma, USA. Agric. Water Manag. 2018, 204, 47-59. [CrossRef]

32. Dennis Baldocchi, E.F. FLUXNET: A New Tool to Study the Temporal and Spatial Variability of Ecosystem-Scale Carbon Dioxide, Water Vapor, and Energy Flux Densities. Am. Meteorol. Soc. 2001, 82, 2415-2434. [CrossRef]

33. Kucharik, C.J.; Barford, C.C.; Maayar, M.E.; Wofsy, S.C.; Monson, R.K.; Baldocchi, D.D. A multiyear evaluation of a Dynamic Global Vegetation Model at three AmeriFlux forest sites: Vegetation structure, phenology, soil temperature, and $\mathrm{CO}_{2}$ and $\mathrm{H}_{2} \mathrm{O}$ vapor exchange. Ecol. Model. 2006, 196, 1-31. [CrossRef]

34. Papale, D. Effect of spatial sampling from European flux towers for estimating carbon and water fluxes with artificial neural networks. J. Geophys. Res. Biogeosci. 2015, 120, 1941-1957. [CrossRef]

35. Fu, Y.-L. Depression of net ecosystem $\mathrm{CO}_{2}$ exchange in semi-arid Leymus chinensis steppe and alpine shrub. Agric. For. Meteorol. 2006, 137, 234-244. [CrossRef]

36. Vuichard, N. Filling the gaps in meteorological continuous data measured at FLUXNET sites with ERA-Interim reanalysis. Earth Syst. Sci. Data 2015, 7, 157-171. [CrossRef]

37. Xiao, X. Light Absorption by Leaf Chlorophyll and Maximum Light Use Efficiency. IEEE Trans. Geosci. Remote Sens. 2006, 44, 1933-1935. [CrossRef]

38. Zhao, M.; Running, S.W. Drought-Induced Reduction in Global Terrestrial Net Primary Production from 2000 through 2009. Science 2010, 329, 940-943. [CrossRef] [PubMed]

39. Reichstein, M. On the separation of net ecosystem exchange into assimilation and ecosystem repiration:review and improved algorithm. Glob. Chang. Biol. 2005, 11, 1424-1439. [CrossRef]

40. Piñeiro, G.; Perelman, S.; Guerschman, J.P.; Paruelo, J.M. How to evaluate models: Observed vs. predicted or predicted vs. observed? Ecol. Model. 2008, 216, 316-322. [CrossRef]

41. Goulden, M.L.; Daube, B.C.; Fan, S.M.; Sutton, D.J.; Bazzaz, A.; Munger, J.W.; Wofsy, S.C. Physiological responses of a black spruce forest to weather. J. Geophys. Res. Atmos. 1997, 102, 28987-28996. [CrossRef]

42. Xiao, X.M.; Hollinger, D.; Aber, J.; Goltz, M.; Davidson, E.A.; Zhang, Q.Y.; Moore, B. Satellite-based modeling of gross primary production in an evergreen needleleaf forest. Remote Sens. Environ. 2004, 89, 519-534. [CrossRef]

43. Frolking, S.E.; Bubier, J.L.; Moore, T.R.; Ball, T.; Bellisario, L.M.; Bhardwaj, A.; Carroll, P.; Crill, P.M.; Lafleur, P.M.; Mccaughey, J.H. Relationship between ecosystem productivity and photosynthetically active radiation for northern peatlands. Glob. Biogeochem. Cycles 1998, 12, 115-126. [CrossRef]

44. Ruimy, A.; Dedieu, G.; Saugier, B. TURC: A diagnostic model of continental gross primary productivity and net primary productivity. Glob. Biogeochem. Cycles 1996, 10, 269-285. [CrossRef]

45. Ruimy, A.; Jarvis, P.G.; Baldocchi, D.D.; Saugier, B. $\mathrm{CO}_{2}$ Fluxes over Plant Canopies and Solar Radiation: A Review. Adv. Ecol. Res. 1995, 26, 1-68.

46. Turner, D.P.; Ritts, W.D.; Cohen, W.B.; Maeirsperger, T.K.; Gower, S.T.; Kirschbaum, A.A.; Running, S.W.; Zhao, M.; Wofsy, S.C.; Dunn, A.L.; et al. Site-level evaluation of satellite-based global terrestrial gross primary production and net primary production monitoring. Glob. Chang. Biol. 2005, 11, 666-684. [CrossRef]

47. Xiao, J.; Zhuang, Q.; Law, B.E.; Chen, J.; Baldocchi, D.D.; Cook, D.R.; Oren, R.; Richardson, A.D.; Wharton, S.; $\mathrm{Ma}$, S.; et al. A continuous measure of gross primary production for the conterminous United States derived from MODIS and AmeriFlux data. Remote Sens. Environ. 2010, 114, 576-591. [CrossRef]

48. Wu, C.; Chen, J.M.; Huang, N. Predicting gross primary production from the enhanced vegetation index and photosynthetically active radiation: Evaluation and calibration. Remote Sens. Environ. 2011, 115, 3424-3435. [CrossRef] 
49. Gu, Y.; Wylie, B.K.; Bliss, N.B. Mapping grassland productivity with 250-m eMODIS NDVI and SSURGO database over the Greater Platte River Basin, USA. Ecol. Indic. 2013, 24, 31-36. [CrossRef]

50. Propastin, P.; Ibrom, A.; Knohl, A.; Erasmi, S. Effects of canopy photosynthesis saturation on the estimation of gross primary productivity from MODIS data in a tropical forest. Remote Sens. Environ. 2012, 121, 252-260. [CrossRef]

51. Wu, W.; Wang, S.; Xiao, X.; Yu, G.; Fu, Y.; Hao, Y. Modeling gross primary production of a temperate grassland ecosystem in Inner Mongolia, China, using MODIS imagery and climate data. Sci. China Ser. D Earth Sci. 2008, 51, 1501-1512. [CrossRef]

52. Wang, X.; Ma, M.; Huang, G.; Veroustraete, F.; Zhang, Z.; Song, Y.; Tan, J. Vegetation primary production estimation at maize and alpine meadow over the Heihe River Basin, China. Int. J. Appl. Earth Obs. Geoinf. 2012, 17, 94-101. [CrossRef]

53. Zhou, Y.; Zhang, L.; Xiao, J.; Chen, S.; Kato, T.; Zhou, G. A Comparison of Satellite-Derived Vegetation Indices for Approximating Gross Primary Productivity of Grasslands. Rangel. Ecol. Manag. 2014, 67, 9-18. [CrossRef]

54. Zhang, Y.; Xiao, X.; Wolf, S.; Wu, J.; Wu, X.; Gioli, B.; Wohlfahrt, G.; Cescatti, A.; van der Tol, C.; Zhou, S.; et al. Spatio-temporal Convergence of Maximum Daily Light-Use Efficiency Based on Radiation Absorption by Canopy Chlorophyll. Geophys. Res. Lett. 2018, 45, 3508-3519. [CrossRef]

55. Liu, Z.; Wu, C.; Peng, D.; Wang, S.; Gonsamo, A.; Fang, B.; Yuan, W. Improved modeling of gross primary production from a better representation of photosynthetic components in vegetation canopy. Agric. For. Meteorol. 2017, 233, 222-234. [CrossRef]

56. Li, F.; Wang, X.F.; Zhao, J.; Zhang, X.Q.; Zhao, Q.J. A method for estimating the gross primary production of alpine meadows using MODIS and climate data in China. Int. J. Remote Sens. 2013, 34, 8280-8300. [CrossRef]

57. Goulden, S.D. Diel and seasonal patterns of tropical forest $\mathrm{CO}_{2}$-exchange. Ecol. Appl. 2004, 14, 542-554. [CrossRef]

58. Turner, D.P.; Ritts, W.D.; Cohen, W.B.; Gower, S.T.; Running, S.W.; Zhao, M.; Costa, M.H.; Kirschbaum, A.A.; Ham, J.M.; Saleska, S.R.; et al. Evaluation of MODIS NPP and GPP products across multiple biomes. Remote Sens. Environ. 2006, 102, 282-292. [CrossRef]

59. Lagergren, F. Net primary production and light use efficiency in a mixed coniferous forest in Sweden. Plant Cell Environ. 2005, 28, 412-423. [CrossRef]

60. Zhang, Y. A global moderate resolution dataset of gross primary production of vegetation for 2000-2016. Sci. Data 2017, 4, 170165. [CrossRef] [PubMed]

61. Dong, J.W.; Xiao, X.M.; Wagle, P.; Zhang, G.L.; Zhou, Y.T.; Jin, C.; Torn, M.S.; Meyers, T.P.; Suyker, A.E.; Wang, J.B.; et al. Comparison of four EVI-based models for estimating gross primary production of maize and soybean croplands and tallgrass prairie under severe drought. Remote Sens. Environ. 2015, 162, 154-168. [CrossRef]

62. Yi, Y.; Kimball, J.S.; Jones, L.A.; Reichle, R.H.; McDonald, K.C. Evaluation of MERRA land surface estimates in preparation for the soil moisture active passive mission. J. Clim. 2011, 24, 3797-3816. [CrossRef]

63. Guttman, N.B. Accepting the Standardized Precipitation Index: A Calculation Algorithm. Jawra J. Am. Water Resour. Assoc. 2010, 35, 311-322. [CrossRef]

64. Seiler, R.A.; Hayes, M.; Bressan, L. Using the standardized precipitation index for flood risk monitoring. Int. J. Climatol. 2002, 22, 1365-1376. [CrossRef]

65. Tao, X.e.; Chen, H.; Xu, C. Characteristics of drought variations in Hanjiang Basin in 1961-2014 based on SPI/SPEI. J. Water Resour. Res. 2015, 4, 404. [CrossRef]

66. Zhang, L.; Wylie, B.; Loveland, T.; Fosnight, E.; Tieszen, L.L.; Ji, L.; Gilmanov, T. Evaluation and comparison of gross primary production estimates for the Northern Great Plains grasslands. Remote Sens. Environ. 2007, 106, 173-189. [CrossRef]

67. Hwang, T.; Kang, S.; Kim, J.; Kim, Y.; Lee, D.; Band, L. Evaluating drought effect on MODIS Gross Primary Production (GPP) with an eco-hydrological model in the mountainous forest, East Asia. Glob. Chang. Biol. 2008, 14, 1037-1056. [CrossRef]

68. Akmal, M.; Janssens, M.J.J. Productivity and light use efficiency of perennial ryegrass with contrasting water and nitrogen supplies. Field Crops Res. 2004, 88, 143-155. [CrossRef] 
69. Hashimoto, H.; Wang, W.; Milesi, C.; Xiong, J.; Ganguly, S.; Zhu, Z.; Nemani, R. Structural Uncertainty in Model-Simulated Trends of Global Gross Primary Production. Remote Sens. 2013, 5, 1258-1273. [CrossRef]

70. Lee, M.; Manning, P.; Rist, J.; Power, S.A.; Marsh, C. A global comparison of grassland biomass responses to $\mathrm{CO}_{2}$ and nitrogen enrichment. Philos. Trans. R. Soc. Lond. B 2010, 365, 2047-2056. [CrossRef] [PubMed]

(c) 2018 by the authors. Licensee MDPI, Basel, Switzerland. This article is an open access article distributed under the terms and conditions of the Creative Commons Attribution (CC BY) license (http:/ / creativecommons.org/licenses/by/4.0/). 